\title{
The Relationship between Energy-dependent Phagocytosis and the Rate of Oxygen Consumption in Tetrahymena
}

\author{
By L. SKRIVER* AND J. R. NILSSON \\ Institute of General Zoology, University of Copenhagen, \\ 15 Universitetsparken, DK-2100 Copenhagen $\varnothing$, Denmark
}

(Received 5 April 1978)

The induction of high rates of food vacuole formation in Tetrahymena pyriformis increased the rate of respiration in exponentially growing cells by $17 \%$ and in starving cells by $47.5 \%$. The increased rate of oxygen uptake was caused by phagocytosis itself, as shown by comparing the rates of respiration of a Tetrahymena mutant exposed to particles at the permissive or restrictive temperatures for food vacuole formation. During cell division, heat-synchronized cells in rich, particle-supplemented medium showed a significant decrease in the rate of respiration. Furthermore, dimethyl sulphoxide, in concentrations sufficient to block food vacuole formation, suppressed the rate of respiration to a level similar to that of starved cells. Cytochalasin B, however, did not reduce the rate of oxygen uptake despite the inability of the cells to complete the formation of food vacuoles during treatment; a possible explanation for this finding is discussed. There was a strong correlation between formation of food vacuoles and a high metabolic rate in Tetrahymena.

\section{INTRODUCTION}

In nature, the ciliate Tetrahymena pyriformis is a suspension feeder; particulate material is carried by means of the oral cilia to the cytostome where food vacuoles are formed. The ease of cultivation and rapid growth rate of this organism make it especially suitable for the experimental study of phagocytosis.

Since formation of food vacuoles in Tetrahymena is dependent on environmental conditions (Nilsson, 1972, 1976), variations in these conditions offer possibilities for exploring the relationship between cellular metabolism and food vacuole formation. The ingestion of particles depends on oxidative phosphorylation (Chapman-Andresen \& Nilsson, 1968); hence it is relevant to investigate how much energy Tetrahymena expends on phagocytosis.

The present investigation provides an estimate of the amount of energy spent in the process of forming food vacuoles in exponentially growing and starving cells.

\section{METHODS}

Organisms and growth conditions. Tetrahymena pyriformis GL8 (Borden et al., 1973) and Tetrahymena thermophila NP1 were grown axenically in a $2 \%(\mathrm{w} / \mathrm{v})$ proteose peptone (PP) medium enriched with $0.1 \%$ $(\mathrm{w} / \mathrm{v})$ liver extract and salts (Plesner et al., 1964). Cells fixed in $2 \%(\mathrm{v} / \mathrm{v})$ glutaraldehyde were counted using either a calibrated counting chamber or a Coulter counter, model ZB; no significant difference in cell number was found between the two methods. Normally, $100 \mathrm{ml}$ cultures were grown in $450 \mathrm{ml}$ Fernbach flasks at $28{ }^{\circ} \mathrm{C}$ and aerated with filtered air at approximately $0.51 \mathrm{~min}^{-1}$. Under these conditions earlystationary phase was reached at a density of about $2 \times 10^{5}$ cells $\mathrm{ml}^{-1}$. In most experiments a density of $0 \cdot 5 \times$ $10^{5}$ to $1.5 \times 10^{5}$ cells $\mathrm{ml}^{-1}$ was used. For studies involving starved cells, an exponential phase culture was

* Present address: Zoophysiological Laboratory C, August Krogh Institute, 13 Universitetsparken, DK-2100 Copenhagen $\emptyset$, Denmark. 
washed twice and subsequently suspended in an inorganic medium (Hamburger \& Zeuthen, 1957). Cell division of $T$. pyriformis was synchronized using the 'one heat-shock per generation technique' described by Zeuthen (1971) except that the cultures were not shaken. The division index was determined microscopically by counting at least 100 cells. Synchronized cells for analysis or for respiration measurements were transferred immediately after the last heat shock.

Measurements of respiration. Oxygen uptake was measured by Warburg manometry using the interval method of Umbreit et al. (1964). The flasks contained between 1.8 and $2.2 \mathrm{ml}$ of cell culture in the main chamber and $200 \mu \mathrm{l}$ of $5 \mathrm{M}-\mathrm{KOH}$ solution for $\mathrm{CO}_{2}$ absorption in the centre well. The side-arms of the flasks were loaded with an appropriate amount of test compound in the same medium as the cells. Controls containing only medium in the side-arm were included in all experiments. The temperature was regulated within $\pm 0.05 \mathrm{C}$. An error of less than $8 \%$ per manometer reading was obtained by adjusting the number of cells incubated in the Warturg flasks. After calibration and initial readings for $\mathrm{O}_{2}$ uptake, the cell suspension was mixed with the contents of the side-arm and the rate of respiration was measured at intervals. The rates of food vacuole formation and cell multiplication, with or without test material, were also assessed in a sample of the original culture incubated under conditions similar to those in the respirometer. Close agreement was found with respect to the final cell density. The partial pressure of $\mathrm{O}_{2}$ dissolved in the medium was measured using a $\rho \mathrm{O}_{2}$-electrode (Radiometer). The rate of food vacuole formation was tested by exposure to carmine particles, as described previously (Nilsson, 1972).

Experiments using the mouthless Tetrahymena mutant. The temperature-sensitive mutant (NP1) of $T$. thermophila forms food vacuoles when grown at $28^{\circ} \mathrm{C}$ but not at $37^{\circ} \mathrm{C}$ (Orias \& Pollock, 1975). This organism was used to assess the effect of particles on chemically uninhibited cells that were unable to form food vacuoles. Three parallel cultures were inoculated at $28{ }^{\circ} \mathrm{C}$; one received the usual inoculum, and the other two received fewer cells in order to prolong the period before stationary phase was reached. The first culture was used at $28{ }^{\circ} \mathrm{C}$ for measurements of respiration, cell growth and vacuole formation. The other two cultures were warmed to $37^{\circ} \mathrm{C}$ and kept at this temperature for $24 \mathrm{~h}$. Then one of them was tested in a manner similar to the first culture. To ascertain whether the cells recover their ability to form food vacuoles, the remaining culture was returned to $28^{\circ} \mathrm{C}$ and the rate of respiration was measured after $2 \mathrm{~d}$.

Chemicals. All were reagent grade and used without further purification. Cytochalasin B (AGA Chemie, Hildesheim, W. Germany) was dissolved in dimethyl sulphoxide (Hopkins \& Williams) to form a stock solution of $10 \mathrm{mg} \mathrm{ml}^{-1}$. Powdered carmine was purchased from Merck.

\section{RESULTS}

\section{Effect of food vacuole formation on respiration of growing and starved cells}

Tetrahymena takes up carmine particles immediately into food vacuoles (ChapmanAndresen \& Nilsson, 1968). Experiments were designed to test whether this uptake of particles was accompanied by an increase in the rate of $\mathrm{O}_{2}$ consumption by the cells. The rate of $\mathrm{O}_{2}$ uptake was measured before and every $20 \mathrm{~min}$ after the addition of carmine particles to exponentially growing cells in PP medium (Table 1; pooled results of four experiments). Initially, the rate of $\mathrm{O}_{2}$ consumption appeared to be significantly higher in the particle-treated cells than in the controls (Table 1,60 min), whereas little difference was seen thereafter. The apparent inhomogeneity among the standard deviations (Table 1) prompted an analysis of variance to check the significance of these results (Table 2). Two out of the four experiments showed a significant difference between the control and carmine-treated samples $(P<0.001)$. Furthermore, all four experiments differed with respect to the $\mathrm{O}_{2}$ consumption at different times. The interaction among the groups tested indicated an effect of particle supplementation on the rate of respiration. The apparent carmine-induced increase in $\mathrm{O}_{2}$ uptake during the first $20 \mathrm{~min}$ after addition of particles was then tested against uptake at all the other times by an 'a priori comparison' (Sokal \& Rohlf, 1969) of the means. The significance level, better than $0 \cdot 1 \%$, indicated that the particle effect was localized to the first 20 min after addition of carmine.

In a further 19 experiments the $\mathrm{O}_{2}$ consumption was measured at greater time intervals than in the initial experiments. The pooled results of the initial experiments had revealed a $17 \%$ respiratory increase $(P<0.01)$ in carmine-treated samples over the level in the control samples. An additional effect, not observed in the experiments involving analysis of variance, was a respiratory decrease to $88 \%(P<0.02)$ of the control value during the second 
Table 1. Oxygen uptake by untreated and carmine-treated Tetrahymena pyriformis

\begin{tabular}{lcccccc}
\multicolumn{1}{c}{ Time (min) } & 20 & 40 & 60 & 80 & 100 & 120 \\
Untreated (control) & $178 \cdot 4 \pm 24 \cdot 8$ & $172 \cdot 0 \pm 21 \cdot 4$ & $191 \cdot 2 \pm 26 \cdot 7$ & $186 \cdot 5 \pm 16 \cdot 5$ & $197 \cdot 4 \pm 32 \cdot 4$ & $195 \cdot 5 \pm 13 \cdot 6$ \\
Carmine-treated & $187 \cdot 8 \pm 28 \cdot 8$ & $187 \cdot 8 \pm 37 \cdot 1$ & $251 \cdot 4 \pm 54 \cdot 2$ & $186 \cdot 7 \pm 42 \cdot 5$ & $196 \cdot 1 \pm 33 \cdot 5$ & $211 \cdot 5 \pm 15 \cdot 0$
\end{tabular}

Results show the means of four experiments \pm S.D., expressed as $\mu 1 \mathrm{O}_{2} \mathrm{~h}^{-1}\left(10^{6} \text { cells }\right)^{-1}$.

Table 2. An analysis of variance of the means of data given in Table 1

\begin{tabular}{|c|c|c|c|c|c|c|c|c|c|}
\hline \multirow[b]{2}{*}{$\begin{array}{l}\text { Source of } \\
\text { variation }\end{array}$} & \multirow{2}{*}{$\begin{array}{c}\text { Degrees } \\
\text { of } \\
\text { freedom }\end{array}$} & \multicolumn{2}{|c|}{ Expt 1} & \multicolumn{2}{|c|}{ Expt 2} & \multicolumn{2}{|c|}{ Expt 3} & \multicolumn{2}{|c|}{ Expt 4} \\
\hline & & $\begin{array}{l}\text { Mean } \\
\text { square }\end{array}$ & $\underset{\text { value }}{\mathrm{F}}$ & $\begin{array}{l}\text { Mean } \\
\text { square }\end{array}$ & $\underset{\text { value }}{\mathbf{F}}$ & $\begin{array}{l}\text { Mean } \\
\text { square }\end{array}$ & $\begin{array}{c}\mathbf{F} \\
\text { valuet }\end{array}$ & $\begin{array}{l}\text { Mean } \\
\text { square }\end{array}$ & $\begin{array}{c}F \\
\text { valuet }\end{array}$ \\
\hline $\begin{array}{l}\text { A: Carmine/ } \\
\text { Control }\end{array}$ & 1 & $17 \cdot 8$ & 0.04 & $14181 \cdot 5$ & $24 \cdot 6 * * *$ & $20201 \cdot 3$ & $38 \cdot 0 * * *$ & $58 \cdot 5$ & $0 \cdot 24$ \\
\hline $\begin{array}{c}\text { B: Untake } \\
\text { intervals }\end{array}$ & 5 & $12806 \cdot 0$ & $26 \cdot 2 * * *$ & $2937 \cdot 2$ & $10 \cdot 2 * * *$ & $3766 \cdot 5$ & $7 \cdot 1 * * *$ & $1429 \cdot 2$ & $6 \cdot 2^{* * *}$ \\
\hline $\begin{array}{l}\mathrm{A} \times \mathrm{B} \text { inter- } \\
\text { action }\end{array}$ & 5 & $3238 \cdot 3$ & $6 \cdot 6 * * *$ & $2756 \cdot 9$ & $4 \cdot 7^{* *}$ & $1161 \cdot 4$ & $2 \cdot 2$ & $1729 \cdot 7$ & $7 \cdot 5^{* * *}$ \\
\hline \multirow{2}{*}{$\begin{array}{l}\text { Error within } \\
\text { subgroups }\end{array}$} & 42 & $489 \cdot 4$ & & $588 \cdot 8$ & & $531 \cdot 9$ & & $231 \cdot 1$ & \\
\hline & & $F_{0.005(5}$ & ${ }_{42)}=4.01$ & $F_{0.001}$ & ${ }_{42)}=5.09$ & $F_{0.001(1}$ & ${ }_{42)}=12 \cdot 54$ & & \\
\hline
\end{tabular}

20 min interval after the addition of carmine. This effect was probably due to the greatly reduced rate of food vacuole formation observed about $20 \mathrm{~min}$ after induction of particle uptake (Nilsson, 1972).

If a correlation exists between the ingestion of particles and an increased $\mathrm{O}_{2}$ uptake, then this feature should be accentuated in starving cells which have a higher rate of food vacuole formation (Nilsson, 1972) and a relatively low rate of oxygen uptake (Hamburger \& Zeuthen, 1957). Cells starved for $2 \mathrm{~h}$ and then exposed to carmine particles showed an $\mathrm{O}_{2}$ uptake of $47.5 \%(P<0.001)$ above that of the control starved cells during the first $20 \mathrm{~min}$ interval. However, no reduction of $\mathrm{O}_{2}$ consumption like that found in the growing cells could be detected during the second 20 min interval.

\section{Food vacuole formation and oxygen uptake by a temperature-sensitive mutant}

To test the possibility that the addition of carmine particles to the medium might increase its viscosity, so that the extra effort required for locomotion might increase the $\mathrm{O}_{2}$ consumption of the cells, the rate of respiration of a temperature-sensitive mutant (NP1) of $T$. thermophila was measured. This mutant grew and formed food vacuoles at $28{ }^{\circ} \mathrm{C}$ at a rate similar to that of $T$. pyriformis (Fig. 1). However, at $37^{\circ} \mathrm{C}$, daughter cells of the mutant are unable to form food vacuoles (Orias \& Pollock, 1975) and, although the cells divided, only a fourfold increase in cell density was reached after $24 \mathrm{~h}$. At this time only about $6 \%$ of the cells would be expected to form food vacuoles. On returning the cells to $28{ }^{\circ} \mathrm{C}$, functional mouths are regenerated so that food vacuoles could be formed. The $\mathrm{O}_{2}$ uptake of the mutant at $28{ }^{\circ} \mathrm{C}$ was almost the same as that of $T$. pyriformis at this temperature, and the temporary increase $(11 \%)$ in $\mathrm{O}_{2}$ consumption following addition of carmine particles was restricted to the initial period after addition. The respiration of the mutant cells at $37{ }^{\circ} \mathrm{C}$ did not exceed that of $T$. pyriformis at $28^{\circ} \mathrm{C}$, although the higher temperature would be expected to raise the metabolic rate by a factor of two. Addition of carmine particles to the mutant cells at $37^{\circ} \mathrm{C}$ had no effect on the rate of $\mathrm{O}_{2}$ consumption. However, $48 \mathrm{~h}$ after returning the cells to $28{ }^{\circ} \mathrm{C}$, addition of carmine particles resulted in an increase in the rate of $\mathrm{O}_{2}$ uptake of $50 \%$ and $20 \%$, respectively, in the two experiments. 


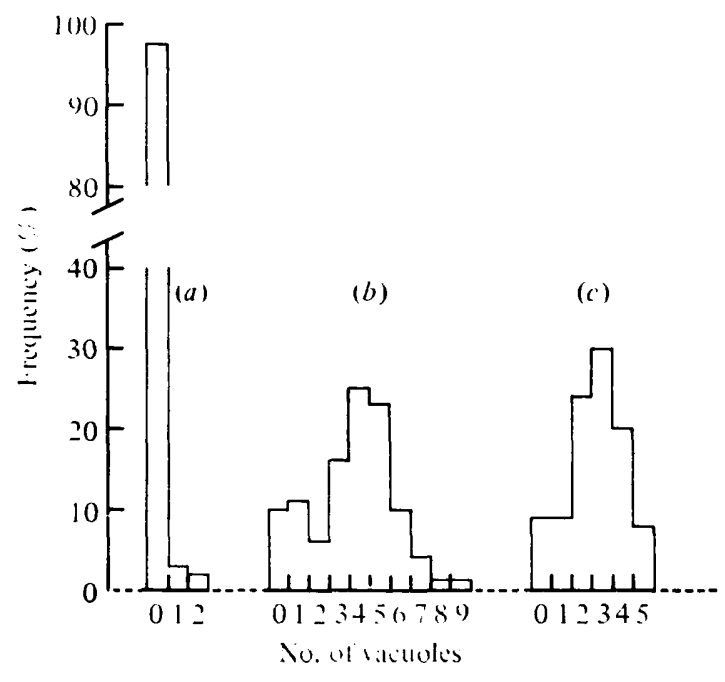

Fig. 1. Food vacuole-forming capacity of Tetrahymena: (a) $T$. thermophila NP1 at $37^{\circ} \mathrm{C} ;(b) T$. thermophila NP1 at $28{ }^{\circ} \mathrm{C}$; (c) T. pyriformis GL 8 at $28^{\circ} \mathrm{C}$. All cells were exposed to carmine particles for $10 \mathrm{~min}$.

Thus the presence of particles in the medium did not cause an increase in the rate of $\mathrm{O}_{2}$ uptake unless particle addition was followed by ingestion.

\section{Oxygen uptake in synchronized cells exposed to carmine particles}

The finding that food vacuole formation was accompanied by an increased rate of respiration was further tested in a chemically uninhibited system of heat-synchronized $T$. pyriformis.

Cells incubated at $28{ }^{\circ} \mathrm{C}$ after the sixth heat shock had a respiration rate of about twice that of exponentially growing cells (Table $1,80 \mathrm{~min}$ ). Since phagocytosis is a discontinuous process during the cell cycle of Tetrahymena, with a cessation in food vacuole formation for about 30 min around cell division (Chapman-Andresen \& Nilsson, 1968), a drop in $\mathrm{O}_{2}$ uptake would be expected during this interval. Indeed in three experiments, one of which is shown in Fig. 2, cells in PP medium supplemented with carmine particles showed a sharp decrease in respiration during the first synchronous division. During the second synchronous division, this effect was only observed in one of the three experiments, possibly due to the fact that the second division peak, as indicated by the percentage of cells dividing (division index), was less well defined (Fig. $2 a$ ). Cells washed and placed in non-nutrient medium in the middle of the last heat shock had a significantly lower rate of respiration compared with synchronized cells in PP medium. The rate of respiration in the starved cells declined uniformly without any additional decrease during cell division, thus supporting the concept that the reduced rate of $\mathrm{O}_{2}$ uptake during cell division in the PP medium was due to an inability of the cells to form food vacuoles (Fig. $2 b$ ).

\section{Effect of inhibitors of phagocytosis on the rate of respiration}

Since the cells use a certain amount of energy during phagocytosis, measurements of $\mathrm{O}_{2}$ uptake following administration of inhibitors of food vacuole formation might indicate the physiological importance of the apparently close relationship between rate of respiration and food vacuole formation.

Food vacuole formation is totally blocked in fast-growing cells treated with $7.5 \%(\mathrm{v} / \mathrm{v})$ dimethyl sulphoxide (DMSO) for $1 \mathrm{~h}$ prior to addition of carmine particles, while a reduction to $85 \%$ and $50 \%$ of the control value occurs in $2.5 \%$ and $5 \%$ DMSO, respectively 


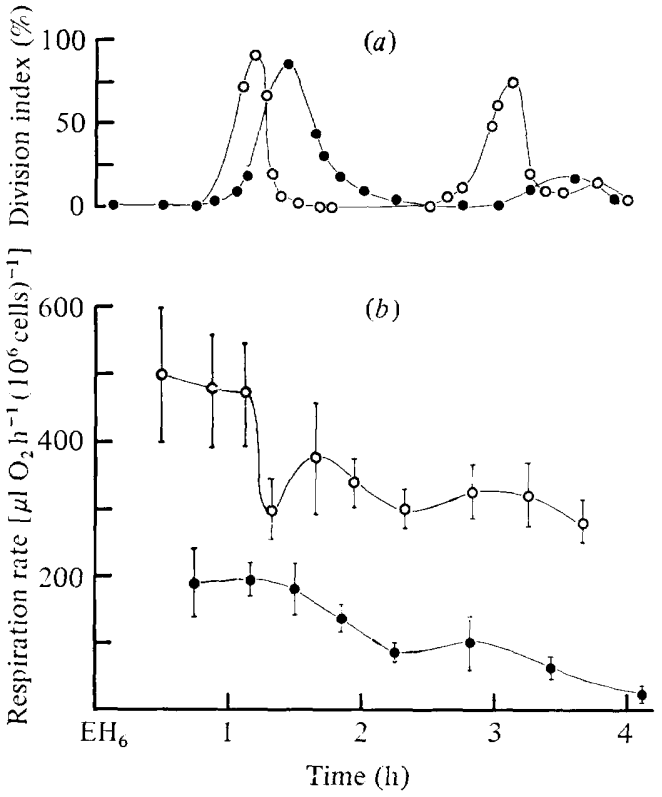

Fig. 2

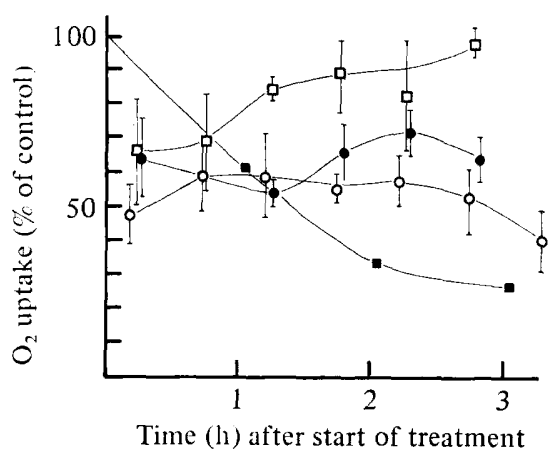

Fig. 3

Fig. 2. Division index, i.e. percentage of dividing cells, $(a)$ and the rate of respiration $(b)$ of heatsynchronized Tetrahymena pyriformis GL 8 in proteose peptone medium $(O)$ or in inorganic medium (O). Results show the means of eight determinations \pm S.D. $\mathrm{EH}_{6}$ denotes the end of the sixth heat shock. Carmine particles were added $1 \mathrm{~h}$ after $\mathrm{EH}_{6}$.

Fig. 3. Inhibition of oxygen consumption by Tetrahymena pyriformis GL 8 exposed to various concentrations of DMSO in proteose peptone medium (mean of four experiments \pm S.D.) or to initial starvation in inorganic medium (mean of two experiments): $0,7.5 \% \mathrm{DMSO} ; 0,5.0 \%$ DMSO; $\square, 2.5 \%$ DMSO; $\mathbf{\square}$, cells washed and suspended in inorganic medium at time 0 .

(Nilsson, 1974). Cells were incubated in the presence of these three concentrations of DMSO and their rates of respiration were followed for $3 \mathrm{~h}$ (Fig. 3). The observed suppression of cellular respiration in DMSO followed very closely the decreased capacity of the cells to form food vacuoles. For concentrations of DMSO up to $2.5 \%$ the $\mathrm{O}_{2}$ uptake was not significantly reduced compared with control cells after $3 \mathrm{~h}$ incubation. In $5 \%$ DMSO, which caused a $50 \%$ reduction in phagocytosis, the respiration was only $60 \%$ of the control value. Furthermore, the total suppression of food vacuole formation by $7.5 \%$ DMSO caused the rate of respiration to drop to $40 \%$ of the control value for cells in PP medium, a level approximately equal to that found in cells starved for the same length of time. The addition of DMSO to PP medium and inorganic medium caused no change in their $\mathrm{O}_{2}$ content.

Cells starved for $1 \mathrm{~h}$ and treated with $7.5 \%$ DMSO showed an initial decrease in $\mathrm{O}_{2}$ consumption of a magnitude similar to that of exponentially growing cells. As the cells recovered from the initial effect of the DMSO, they returned to the normal reduced rate of respiration seen in starved cells. Thus if DMSO is metabolized by Tetrahymena, it does not serve as a source of energy.

The experimental conditions so far discussed resulted in complete inhibition of all stages in food vacuole formation and no accumulation of particles or solutes in vacuolar structures was observed. However, when cells are exposed to $37 \mu \mathrm{g}$ cytochalasin $\mathrm{B} \mathrm{ml}^{-1}$ in PP medium a large open food vacuole is formed at the cytostome (Nilsson, 1977). On addition of carmine, cells rapidly accumulated particles in this structure, but no food vacuoles containing carmine particles were completed. However, electron micrographs of cytochalasin B-treated cells show the presence of small vacuoles, which do not contain particles, in the cytoplasm; these are not found in control cells (Nilsson, 1977). When exponentially growing 
cells were incubated with $37 \mu \mathrm{g}$ cytochalasin $\mathrm{B} \mathrm{ml} \mathrm{m}^{-1}$, the rate of $\mathrm{O}_{2}$ uptake was slightly reduced initially, but the respiration rate stabilized at a level close to normal during the first 1 to $2 \mathrm{~h}$, after which it was suppressed gradually to $70 \%$ of the control rate.

\section{DISCUSSION}

Previous work with $T$. pyriformis has shown that the rate of respiration, measured over $30 \mathrm{~min}$ intervals, increases when the cells are fed metabolizable particles, i.e. heat-killed bacteria, but not when the ciliates are exposed to inert particles (Burmeister, 1971). However, Nilsson (1972) showed that the cells reach a peak in their capacity to form food vacuoles within the first $20 \mathrm{~min}$ of exposure to carmine particles. A reduced rate of respiration might be counterbalanced by a cessation of food vacuole formation. This possibility was tested in the present investigation by reducing the intervals between measurements of $\mathrm{O}_{2}$ uptake. The results showed close correspondence between the rate of formation of food vacuoles and the rate of respiration.

The possibility that the particles might increase respiration because of the greater effort required for motility in a particle-supplemented medium of increased viscosity, has been eliminated by measurements on the temperature-sensitive and mouth-deficient Tetrahymena mutant. These cells, tested at the restrictive $\left(37^{\circ} \mathrm{C}\right)$ or permissive $\left(28^{\circ} \mathrm{C}\right)$ temperature for food vacuole formation, showed a particle-mediated increase in $\mathrm{O}_{2}$ uptake only at the lower temperature, where food vacuoles were formed.

The increased rate of respiration could be directly related to the ingestion of particles and the energy spent on phagocytosis may be estimated. The energy (ATP) used in food vacuole formation by exponentially growing cells in well-aerated medium is thought to be generated by oxidative phosphorylation because food vacuole formation is totally inhibited by addition of uncoupling concentrations of dinitrophenol (Nilsson, 1976) and by $1 \mathrm{mm-cyanide}$ (unpublished observations), and inhibition of glycolysis by $\mathrm{O}_{2}$ does not change the rate of food vacuole formation. Furthermore, the ratio of phosphate incorporated into ATP to $\mathrm{O}_{2}$ assimilated $(\mathrm{P} / \mathrm{O})$ in exponentially growing cells is approximately 2 (Kobayashi, 1965) and the cells form 3.5 vacuoles per $20 \mathrm{~min}$, indicating that the individual cell would need to produce $6 \times 10^{-13} \mathrm{~mol}$ ATP in order to form one food vacuole. Using the same assumption, the energy expenditure of cells starved for $2.5 \mathrm{~h}$ would be $4 \times 10^{-13} \mathrm{~mol} \mathrm{ATP}$ for the formation of one food vacuole.

Polymorphonuclear cells, under partially anaerobic conditions, use $1 \times 10^{-15}$ to $2 \times 10^{-15}$ mol ATP during ingestion of one polystyrene particle having a diameter of $1.171 \mu \mathrm{m}$ (Karnovsky, 1962). A food vacuole in Tetrahymena has a volume of $65 \mu \mathrm{m}^{3}$ (diam. $5 \mu \mathrm{m}$ ) and it may accommodate about 50 carmine particles (diam. $1 \mu \mathrm{m}$ ). Hence, the amount of energy spent on the ingestion of one particle is identical for both types of cells and it is independent of the final size of the endocytic vacuole.

The role of food vacuole formation in the metabolism of Tetrahymena may be evaluated by comparing the rate of respiration of vacuole-forming cells with that of cells in which this function is blocked. Although no specific inhibitors of food vacuole formation are known, DMSO and cytochalasin B were used because of their reversible effects on food vacuole formation and cell multiplication (Nilsson, 1974, 1977).

DMSO decreases, in a dose-dependent manner, the rate of respiration of exponentially growing cells to a level corresponding to that of starved cells in which food vacuole formation is not induced. In DMSO-treated cells the fine structure of mitochondria and peroxisomes is changed to the more electron-dense type typical of starved cells (Nilsson, 1976). Furthermore, addition of DMSO followed by addition of carmine particles does not alter the rate of respiration of starved cells. Thus, it may be concluded that DMSO acts on the functioning of the oral apparatus.

The experiments using cytochalasin B as an inhibitor of food vacuole formation gave 
unexpected results as the respiration rate was close to that of untreated cells. The cytochalasin B-treated cells have a large incomplete food vacuole at the cytostome and their generation time is only prolonged by a factor of 1.4 over that of the control cells (Nilsson, 1977). Electron microscopic observations of cytochalasin B-treated cells have revealed the presence of small vacuoles which have a membrane structure similar to that of food vacuoles (Nilsson, 1977). Nutrient uptake via these pinocytic vacuoles might account for the practically uninhibited respiration rate of cytochalasin B-treated cells. However, the efficiency of food uptake through formation of the small vacuoles is less than that of food vacuoles of uninhibited cells. The uptake of nutrients by pinocytic vacuoles does not exclude the possibility of an additional nutrient uptake of free amino acids as discussed by Hoffmann et al. (1974). However, the present results clearly demonstrated that the cellular metabolism was reduced when food vacuole formation was inhibited.

Heat-synchronized cells do not form food vacuoles during cell division (Nachtwey \& Dickinson, 1967; Chapman-Andresen \& Nilsson, 1968). Moreover, the rate of respiration is reduced during this period (Lövlie, 1963; Hamburger \& Zeuthen, 1971); in the present study, the addition of particles did not increase the rate of respiration. These results stress the point that the particle-mediated increase in $\mathrm{O}_{2}$ uptake occurs only if the particles enter food vacuoles and that inhibition of food vacuole formation causes a decrease in cellular metabolism. The same trend was seen in the experiments using the Tetrahymena mutant shifted to the temperature at which the cells do not form food vacuoles or show any increase in the rate of respiration.

Our sincere thanks to Dr E. Orias for the generous gift of the Tetrahymena mutant NP1, to Dr P. Holter for helpful discussions of the statistical analyses, and to Dr C. ChapmanAndresen for use of the $\mathrm{O}_{2}$ electrode equipment and for critical reading of the manuscript. The Coulter counter used in this study was provided by the Danish Natural Science Research Council.

\section{REFERENCES}

Borden, D., WhitT, G. S. \& NANNey, D. L. (1973). Electrophoretical characterization of classical Tetrahymena pyriformis strains. Journal of Protozoology 20, 693-700.

BURMEISTER, J. (1971). Der Stoffwechsel von Tetrahymena pyriformis bei der Aufnahme von Nahrung und unferdaulichen Partikeln. Zeitschrift für allgemeine Mikrobiologie 11(4), 275282.

Chapman-Andresen, C. \& Nilsson, J. R. (1968). On vacuole formation in Tetrahymena pyriformis $\mathrm{GL}$. Comptes rendus des travaux du Laboratoire Carlsberg 36, 405-432.

HAMBURGer, K. \& ZeUthen, E. (1957). Synchronous division in Tetrahymena pyriformis as studied in an inorganic medium. Experimental Cell Research 13, 443-453.

Hamburger, K. \& Zeuthen, E. (1971). Respiratory responses to dissolved food of starved, normal and division synchronized Tetrahymena cells. Comptes rendus des travaux du Laboratoire Carlsberg 38, 145-161.

Hoffmann, E. K., Rasmussen, L. \& Zeuthen, E. (1974). Cytochalasin B: aspects of phagocytosis in nutrient uptake in Tetrahymena. Journal of Cell Science 15, 403-406.

Karnovsky, M. L. (1962). Metabolic basis of phagocytic activity. Physiological Review's 42, 143-168.
Kobayashi, S. (1965). Preparation and properties of mitochondria from the ciliated protozoon Tetrahymena. Journal of Biochemistry 58, $444-456$.

LövLIE, A. (1963). Growth in mass and respiration rate during the cell cycle in Tetrahymena pyriformis. Comptes rendus des travaux du Laboratoire Carlsberg 33, 377-413.

Nachtwey, D.S. \& Dickinson, W. J. (1967). Actinomycin D: blockage of cell division of synchronized Tetrahymena pyriformis. Experimental Cell Research 47, 581-595.

Nilsson, J. R. (1972). Further studies on vacuole formation in Tetrahymena pyriformis GL. Comptes rendus des travaux du Laboratoire Carlsberg 39, 83-110.

Nilsson, J. R. (1974). Effect of DMSO on vacuole formation, contractile vacuole function, and nuclear division in Tetrahymena. Journal of Cell Science 16, 39-47.

Nilsson, J. R. (1976). Physiological and structural studies on Tetrahymena pyriformis GL. Comptes rendus des travaux du Laboratoire Carlsberg $\mathbf{4 0}$, 215-355.

NiLsson, J. R. (1977). Fine structure and RNA synthesis of Tetrahymena during cytochalasin B inhibition of phagocytosis. Journal of Cell Science 27, 115-126.

Orias, E. \& Pollock, N. A. (1975). Heat sensitive development of the phagocytic organelle in a MrC rog 
Tetrahymena mutant. Experimental Cell Research 90, 345-356.

Plesner, P., Rasmussen, L. \& Zeuthen, E. (1964).

Techniques used in the study of synchronous

Tetrakymena. In Synchrony in Cell Division and Growth, pp. 543-563. Edited by E. Zeuthen. New York: Interscience.

SoKal, R.R.\& RohlF, F. J. (1969). Biometry, 1st edn, p. 233. San Francisco: W. H. Freeman and Co.
Umbreit, W. W., Burris, R. H. \& Stauffer, J. F. (1964). Manometric Techniques. Minnesota: Burgess.

ZeUthen, E. (1971). Synchrony in Tetrahymena by heat shocks spaced a normal cell generation apart. Experimental Cell Research 68, 49-60. 